\title{
Farmer-Managed Natural Regeneration enhances rural livelihoods in dryland West Africa
}

\author{
Peter Weston, Reaksmey Hong, Carolyn Kaboré, Christian A. Kull
}

This is the author archived version of a paper published in Environmental Management (Springer).

The correct citation is: Weston, Peter, Reaksmey Hong, Carolyn Kaboré \& Christian A. Kull (2015) Farmermanaged natural regeneration enhances rural livelihoods in dryland West Africa. Environmental Management 55 (6):1402-1417.

Doi: $10.1007 / \mathrm{s} 00267-015-0469-1$

The definitive, official online version is available at http://dx.doi.org/10.1007/s00267-015-0469-1 or http://link.springer.com/article/10.1007\%2Fs00267-015-0469-1

\begin{abstract}
Declining agricultural productivity, land clearance and climate change are compounding the vulnerability of already marginal rural populations in West Africa. 'Farmer-Managed Natural Regeneration' (FMNR) is an approach to arable land restoration and reforestation that seeks to reconcile sustained food production, conservation of soils and protection of biodiversity. It involves selecting and protecting the most vigorous stems regrowing from live stumps of felled trees, pruning off all other stems, and pollarding the chosen stems to grow into straight trunks. Despite widespread enthusiasm and application of FMNR by environmental management and development projects, to date, no research has provided a measure of the aggregate livelihood impact of community adoption of FMNR. This paper places FMNR in the context of other agroforestry initiatives, then seeks to quantify the value of livelihood outcomes of FMNR. We review published and unpublished evidence about the impacts of FMNR, and present a new case study that addresses gaps in the evidence base. The case study focuses on a FMNR project in the district of Talensi in the semi-arid Upper East Region in Ghana. The case study employs a Social Return on Investment (SROI) analysis, which identifies proxy financial values for non-economic as well as economic benefits. The results demonstrate income and agricultural benefits, but also show that asset creation, increased consumption of wild resources, health improvements and psycho-social benefits created more value in FMNR-adopting households during the period of the study than increases in income and agricultural yields.
\end{abstract}

Key words

West Africa, agroforestry, Ghana, land restoration, semi-arid, social return on investment, SROI, FMNR, Farmer-Managed Natural Regeneration

\section{P. Weston,}

World Vision International, Highway Plaza, Kukum Hwy, Honiara, Solomon Islands;

Ph.. +6777496211

Email: work: peter_weston@wvi.org_Home: pedrodevalda@gmail.com

R. Hong

Australian Government Aid Programme, Phnom Penh, Cambodia

C. Kaboré

World Vision International, Australia

\section{A. Kull}

Centre for Geography and Environmental Science, Monash University, Melbourne, Australia and Institut de géographie et durabilité, Université de Lausanne, Switzerland 


\section{INTRODUCTION}

In dryland West Africa a quiet movement appears to be defying trends of declining agricultural productivity and to be alleviating decades of pressure on soil resources and tree cover. This phenomenon is 'Farmer-Managed Natural Regeneration' (FMNR, or Régénération naturelle assistée - RNA - in French), an approach promoted by environment and development NGOs for arable land restoration and reforestation. Proponents of FMNR claim that it reconciles needs for sustained food production, conservation of soils and protection of biodiversity. It is seen as a major contributor to the 're-greening' of a region famed for desertification and degradation. In concrete terms, the approach is centred on an agroforestry practice that seeks to achieve the regeneration of woody plant cover in farming and mixed land use areas. Specifically, FMNR projects work with farmers to protect regrowth from live stumps in their fields that would otherwise be cleared each year (Rands and Rinaudo 1990; Reij ; Rinaudo 2007; Taylor and Rands 1991:49; WRI 2008; Samaké et al. 2011).

From its beginnings thirty years ago, many claims have been made about the benefits of FMNR for re-greening landscapes and restoring rural livelihoods. Yet, arguments for the approach's utility and effectiveness remain patchy, often relying heavily on promotional claims, theoretical modelling, or anecdotes. To date, published original research has focussed on either economic indicators or tree-counting as quantitative proxy contributions to human wellbeing (e.g., Haglund et al. 2011 and Larwanou and Saadou 2011). Other studies have merely described other qualitative benefits (e.g., McGahuey and Winterbottom 2007 and Tougiani et al 2009). Thus, to date, no study has provided a measure of the aggregate livelihood impact of community adoption of FMNR.

As a result, we sought to provide new evidence to quantify the broad livelihood and environmental outcomes of FMNR for subsistence farming households in a new study area in northeast Ghana. The study employs a research methodology called Social Return on Investment (SROI), which entails conceptualising proxy monetary values for social benefits of an initiative (Lingane and Olsen 2004). SROI is advantageous to this topic because many of the benefits claimed about FMNR relate to non-market outcomes that have no direct economic measure. SROI allows us to determine individual and aggregate values of perceived changes upon the livelihoods of households from the adoption of FMNR. Before presenting these results, however, we situate the approach in the broader literature on environment-development challenges in West Africa, and systematically review the published and unpublished evidence about the impacts of FMNR. Together, our paper demonstrates that community-wide adoption of FMNR made a distinct contribution to rural household wellbeing, particularly in terms of increased assets (tree stocks, healthy livestock), increased availability of wild resources (food and construction), improved psycho-social wellbeing, and improved soil fertility and crop yields.

\section{BACKGROUND}

FMNR has principally been developed in the drylands of West Africa. These are the bioclimatic zones that separate the Sahara desert from West Africa's humid coastal equatorial zone. They range from the arid Sahelian zone to the north, with highly variable rainfall totalling $250-500 \mathrm{~mm} / \mathrm{yr}$, to the sub-humid Sudanian zone to the south, with up to 1000 $\mathrm{mm} / \mathrm{yr}$ (UNCCD and CFC 2009). Typically, agriculture in this zone is smallholder pastoralism and seasonal rain-fed crop farming for subsistence and market purposes (Darkoh 2003). 
A number of dynamic pressures are transforming agriculture in West Africa's dryland belt (Mortimore 1998). In general, African agricultural production is declining per capita and productivity per hectare is lower than any other major region of the world (FAO 2009). Drivers include high population growth and neoliberal market reforms that have, among other effects, undermined the capacity of states to provide agricultural services (Moseley et al. 2010; Sanchez and Swaminathan 2005). In addition, land disputes have increased (Bugri 2008) while promotion of certain agricultural projects, markets, and techniques have led to the neglect of biodiversity, soil health and water infiltration (Colchester 1993; Mortimore and Turner 2005). Land clearing for agriculture contributes to habitat conversion and exposed soils. The Sahel lost 28 percent of its natural forest between 1961 and 2002, perhaps contributing to regional rainfall reductions (Taylor et al. 2002). Over the same period, exposed bare land is said to have doubled, and three quarters of all arable land have been affected by soil degradation (Montpellier Panel 2013; Woomer et al. 2004). For farming households whose livelihoods are closely tied to rain-fed agriculture and reliance on natural resources, the deterioration of ecosystems services - such as loss of wild foods, deteriorating soil fertility, and the threat of increased climate variability - elevates their vulnerability and undermines their coping mechanisms (UNDP 2011). Almost 6 million people were estimated to be experiencing severe food insecurity in the region in 2012 (CILSS et al. 2012).

Agroforestry is promoted as a farm and landscape management adaptation to these pressures. Agroforestry seeks to reconcile environmental goals and agricultural productivity by deliberately incorporating and managing trees and shrubs in farmlands or pastures (Simons and Leakey 2004). While such practices have long historical antecedents, formal research in and promotion of agroforestry as an alternative to high-input single-crop fields only began in the 1980s and gained acceptance globally in the 1990s (Leakey et al. 2005). In practice, agroforestry is often adopted to rehabilitate degraded farmland (Bae et al. 2013).

Agroforestry practitioners and researchers make a number of claims about the value of increased diversity and density of on-farm species. Greater tree densities reduce vulnerability to soil erosion (Brechears et al. 2009). Reintroducing indigenous and selected exotic trees into farmland improves soil nutrients and soil organic matter and attracts grazing animals that deposit manure (Franzel 1999). Trees also help increase water infiltration into soil, reduce soil evapotranspiration and reduce soil temperature, which improve annual crops' tolerance of hot and/or dry spells, especially in rainfed agriculture (Brown et al. 2011). Increased densities of indigenous trees and shrubs can lead to greater wildlife diversity, including animal, bird, and insect species (Cunningham and Abasse 2005). For livestock, greater tree density can supplement grass fodder and reduce labour requirements for accessing feed during scarcity (Place et al. 2009). For humans, increased tree cover reduces wind speeds, airborne dust and provides cooling shade (Cunningham and Abasse 2005). In combination, these effects can stabilise and protect farming households' livelihoods (Thorlakson and Neufeldt 2012), diversify income into timber and non-timber tree products (Reij et al. 2009), and improve household resilience to droughts or pests (Brown et al. 2011).

Whereas the broad concept of agroforestry often implies the planting of tree seedlings, the key distinction of FMNR is the absence of planting. FMNR relies on regrowth from live stumps. The already deep, mature roots of the stumps feed regrowth that is stronger and more rapid than planted seedlings, especially in dryland zones, ensuring greater survival rates (Rinaudo 2012; Taylor and Rands 1991; Tougiani et al. 2009). Conventionally, in agricultural fields, regrowth is 
slashed or burned down before each crop-planting season. Under FMNR, as regrowth emerges, the strongest, straightest stems are preserved and pollarded (Figure 1). Other stems are culled. Stumps are selected for species type, spacing, and vigour. The basic techniques require no special inputs, are easily learned and passed on between farmers and can be adapted to each practitioner's own context and purposes. By contrast, conventional tree-planting requires seedling nurseries, transport, special tools and supplementary watering (Rands and Rinaudo 1990; Rinaudo 2007).

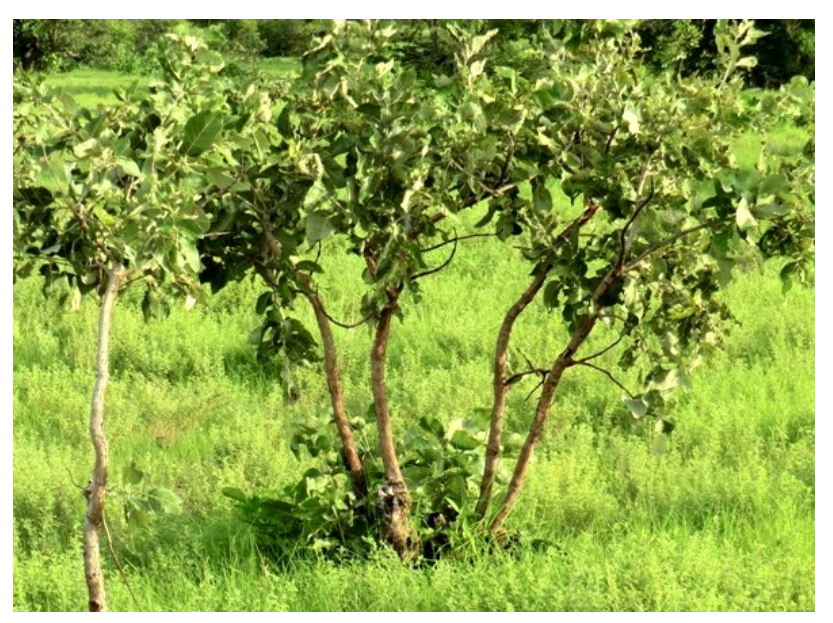

Figure 1: A well-pruned FMNR regrowth from a stump in fallow field in Balungu village in the wet season (photo: lead author, 2012).

The technique that became known as FMNR was first developed in 1983 to protect the livelihoods of poor farmers in the drylands of rural Niger. At that time, a major drought - driven by climatic cycles (Bader and Latif 2011) and following on the heels of the disastrous 1968-1973 drought - contributed to failed crops, wind erosion, and chronic hunger. Because of widespread ideas linking desertification and drought with tree cover, policymakers and environmental managers had, since the 1930s, sought to prevent tree-cutting and encourage the planting of belts of trees (Mortimore 1998). Earlier campaigns of tree-planting in Niger had low seedling survival rates, while agriculture intensification projects had failed to improve food security and incomes. The initial FMNR attempts in Niger were touted as the first sustainable and self-replicating exercise in reforestation in that country. Its success was due to farmers deriving benefits, using farmers' own farm management, and the natural stock of living under-ground tree roots to ensure vigorous regrowth (Rands and Rinaudo 1990; Sendzimir et al. 2011). FMNR is one of a number of land management innovations to emerge from West Africa over recent decades, which include 'zai' planting pits and stone bunds (Reij et al. 2009).

\section{METHODS}

Evidence of FMNR's broad livelihood outcomes has been assembled in two ways. Initially, we reviewed previous assessments of FMNR. In addition to the scientific literature, we assembled unpublished reports by NGOs and multilateral research or development organisations. These were sourced through organisational websites, referral by peers, publication alerts, and document repositories of World Vision Australia, World Agroforestry Centre, Africa Regreening Initiative and the World Resources Institute. 
Next, we sought new empirical evidence through an innovative end-of-project evaluation of a FMNR project in Talensi District, Upper East Region, Ghana in 2012 (we describe the project and its context in the results section). We measured changes in farming practices against baseline data and applied a Social Return on Investment (SROI) analysis. The latter approach offers a novel contribution to filling identified research gaps. SROI is an approach to measure and account for value created by a project intervention or a policy (Wright et al. 2009). The approach is similar to cost-benefit analysis, but enables decision-makers to interpret social and environmental as well as economic value creation (Lingane and Olsen 2004; Wright et al. 2009). Building on practices from health and environmental economics, it establishes proxy monetary values for non-monetary and non-market outcomes of an initiative, then compares these with costs incurred to create those benefits. The approach also facilitates the recording of qualitative and quantitative changes expressed by a project's primary stakeholders, regardless of its original objectives and targets (Nicholls et al. 2012; Wright et al. 2009).

Data were collected using qualitative and quantitative methods. First, we convened twelve focus group discussions. These comprised five male farmer groups, five female farmer groups, and 2 youth groups. A total of 55 women, 59 men, 10 girls and 10 boys participated in discussions. Second, key informant interviews were undertaken with two local officers of the Ministry of Food and Agriculture, a community chief and traditional land custodian, a secretary of a community FMNR group, a FMNR group treasurer, the chief researcher from the National Forestry Research Institute, and key World Vision Ghana personnel. Third, we surveyed 400 households (HHs) about project impacts. Respondents were split into three groups. Lead Households $(\mathrm{n}=104)$ had at least one member of the household who had directly participated in project activities as a member of a FMNR Group. Neighboring Households ( $\mathrm{n}=154)$ also lived within the project area, but did not participate actively in the project. Comparison Households $(\mathrm{n}=142)$ live outside the project area but within the same district, geo-climatic, ethnic and economic zone. Lead HHs were purposely selected; Neighbour HHs and Comparison HHs were randomly selected using transects originating from the approximate centre of the community. The survey tool included several open questions that could record a wide diversity of potential responses. The survey results were compared to a baseline survey conducted three years earlier (Ditto 2009). For some outcomes, proxy financial indicators were not obtained from the focus groups or surveys due to time limitations or because the extent of the impact only became apparent during analysis. These were the value of improved respiratory health, improved aesthetics, carbon sequestration and a number of voluntary uses of people's time to achieve a desired result. In these instances, we applied revealed preference techniques, estimating valuations based on prices of market-traded goods with similar benefits (Nicholls et al. 2012).

Data on tree cover was acquired for both community-managed reforestation reserves and for farmers' fields. For the former, monitoring of tree densities, heights, girth and species/biodiversity counts in four community reserves was provided by the Ghanaian National Forest Research Institute (Akpalu 2012), complemented with pre-project photography of conditions at these sites. Regarding farmers' fields, the household survey asked each respondent to report the area of fields managed by that household and number of trees regrown in the last three years.

Data analysis focused on calculating the values of the diverse benefits and costs identified by respondents. The value of each identified cost or benefit was calculated for one household and multiplied by the number of households reporting that benefit. To avoid the risk of over-claiming, discount factors (Lingane and Olsen 2004; Nicholls et al. 2012) were used to constrain the values of individual social returns. These are based on five factors. Deadweight refers to what 
probably would have happened anyway, if the project did not take place. In most cases, deadweight values were drawn from data gathered from the Comparison group. Displacement refers to negative outcomes transferred outside the project area. The only transfer effect detected that may be taking place is avoided deforestation. Attribution accounts for other non-project drivers of the documented changes. Drop-off estimates the future risk of participants abandoning or losing their benefits. We used discount rates of $0 \%$ to $20 \%$, depending on the benefit in question. Rates were low, due in part to the importance of the benefits described by participants, the institutionalisation of changed practices, and in part due to the short period of forecasting of returns of 4 years after the project. Duration considers how long the outcomes are likely to last. Outcomes from similar projects in Ethiopia (Kabore 2010) and Niger (Reij et al. 2009) suggest that, once farmers adopt FMNR and related practices, they rarely abandon them. Consequently, social returns were calculated for three time periods: immediately after close of project activities; four years after project; and 10 years after the project. Discount Rate for net present value. We used a discount rate of $8.9 \%$ p.a., which is Ghana's predicted inflation rate for 2012-2017 (IMF 2012). The values for each social impact were aggregated into a single total value, and divided by the total cost of project inputs to arrive at a social return on investment ratio for each of three time periods.

\section{REVIEW OF FMNR EVALUATIONS}

The majority of publications about FMNR in Africa are not based on original research (e.g. Garrity et al. 2010; PyeSmith 2013; Reij et al. 2009) but draw on ten studies published either as journal articles or in agency reports (Table 1). Most focus on FMNR in Niger since the 1980s, and highlight three major themes: the impact on tree cover, the impact on income, and the impact on farm yields.

Table 1: Summary of contents of publications containing original research (including practitioner experience) about FMNR, in chronological order.

\begin{tabular}{|c|c|c|c|c|}
\hline Authors & $\begin{array}{c}\text { Peer } \\
\text { reviewed? }\end{array}$ & Location & Type of Benefit & Quantification? \\
\hline $\begin{array}{c}\text { Cunningham and } \\
\text { Abasse } 2005\end{array}$ & No & Maradi, Niger & $\begin{array}{c}\text { Increased income, via sale of } \\
\text { wood, based on farmer } \\
\text { testimony }\end{array}$ & $\begin{array}{l}\text { Farmers intensively } \\
\text { applying FMNR were } \\
\text { earning } 150,000 \mathrm{CFA} \\
\text { francs compared to the } \\
\text { average of } 17,465 .\end{array}$ \\
\hline $\begin{array}{c}\text { Larwanou, } \\
\text { Abdoulaye and Reij } \\
2006\end{array}$ & No & $\begin{array}{l}3 \text { department in } \\
\text { Zinder Region, } \\
\text { Niger }\end{array}$ & $\begin{array}{c}\text { Tree cover expansion in } 3 \\
\text { Regions; benefits to Household } \\
\text { revenues, environment, } \\
\text { agriculture, livestock, food } \\
\text { security and nutritional intake. }\end{array}$ & $\begin{array}{c}\text { Over } 1 \text { million ha } \\
\text { regreened by FMNR. } \\
\text { Household revenues not } \\
\text { quantified }\end{array}$ \\
\hline $\begin{array}{c}\text { McGahuey and } \\
\text { Winterbottom } 2007\end{array}$ & No & $\begin{array}{c}3 \text { Regions of } \\
\text { Niger: Tillaberi, } \\
\text { Tahoua and }\end{array}$ & $\begin{array}{l}\text { Raised optimism; increased } \\
\text { crops and natural resources; soil } \\
\text { and water conservation; }\end{array}$ & Not quantified \\
\hline
\end{tabular}




\begin{tabular}{|c|c|c|c|c|}
\hline & & Maradi & $\begin{array}{c}\text { incomes and food security; } \\
\text { benefits to women, widows and } \\
\text { landless }\end{array}$ & \\
\hline $\begin{array}{c}\text { Tougiani, Guero } \\
\text { and Rinaudo } 2009\end{array}$ & Yes & $\begin{array}{c}\text { Aguie } \\
\text { Department, } \\
\text { Niger }\end{array}$ & $\begin{array}{l}\text { Reduced vulnerability in years } \\
\text { of national food shortage }\end{array}$ & Not quantified \\
\hline $\begin{array}{c}\text { Haglund, } \\
\text { Ndjeunga, Snook } \\
\text { and Pasternak } 2011\end{array}$ & Yes & Maradi, Niger & $\begin{array}{l}\text { Increased income } \\
\text { Increased crop yield } \\
\text { Higher return on labour } \\
\text { investment }\end{array}$ & $\begin{array}{c}\text { Av income among } \\
\text { FMNR Adopters: } 86,104 \\
\text { CFA francs vs. } 62,996 \\
\text { among non-adopters } \\
\text { (difference of } 23,108 \\
\text { CFA francs: USD46) } \\
\text { Crop values of 71,333 } \\
\text { CFA francs vs. } 45,580 \\
\text { among non-adopters } \\
\text { (Difference of 25,753 } \\
\text { CFA francs: USD51) }\end{array}$ \\
\hline Brown et al. 2011 & Yes & $\begin{array}{l}\text { Humbo, } \\
\text { Ethiopia }\end{array}$ & Attract carbon revenues & $\begin{array}{l}\text { USD726,000 of income } \\
\text { for the resident } \\
\text { community over } 10 \text { years } \\
\text { (initially) }\end{array}$ \\
\hline $\begin{array}{c}\text { Larwanou and } \\
\text { Saadou } 2011\end{array}$ & Yes & $\begin{array}{c}3 \text { regions in } \\
\text { Niger }\end{array}$ & $\begin{array}{c}\text { Greater tree species diversity; } \\
\text { more trees; timber shortage } \\
\text { alleviated. }\end{array}$ & $\begin{array}{c}\text { Around } 100 \text { trees per ha. } \\
\text { where previously there } \\
\text { were virtually none. }\end{array}$ \\
\hline $\begin{array}{l}\text { Sendzimir, Reij and } \\
\text { Magnuszewski } 2011\end{array}$ & Yes & $\begin{array}{c}2 \text { Regions in } \\
\text { Niger }\end{array}$ & $\begin{array}{l}\text { Modelling secondary data to } \\
\text { confirm the central role of } \\
\text { FMNR promoted by NGOs in } \\
\text { regreening a large portion of } \\
\text { Niger. }\end{array}$ & 5 million ha reforested \\
\hline Rinaudo 2012 & No & Maradi, Niger & $\begin{array}{l}\text { Increased local economic value. } \\
\text { Increased household income. }\end{array}$ & $\begin{array}{c}\text { Estimated USD } 17 \text { to } 21 \\
\text { million per year } \\
\text { At least USD140 per } \\
\text { year }\end{array}$ \\
\hline $\begin{array}{c}\text { Place and Binam, } \\
2013\end{array}$ & No & $\begin{array}{l}\text { Several sites in } \\
\text { Burkina Faso, } \\
\text { Mali, Niger and } \\
\text { Senegal }\end{array}$ & $\begin{array}{l}\text { Increased value of firewood } \\
\text { harvested consumed and sold } \\
\text { Increased income from sale of } \\
\text { non-timber tree products }\end{array}$ & $\begin{array}{c}\text { Firewood: } \\
\text { Burkina: additional USD } \\
56 \text { to } 170 \text { per year } \\
\text { Mali: additional USD102 } \\
\text { to } 180 \text { per year }\end{array}$ \\
\hline
\end{tabular}




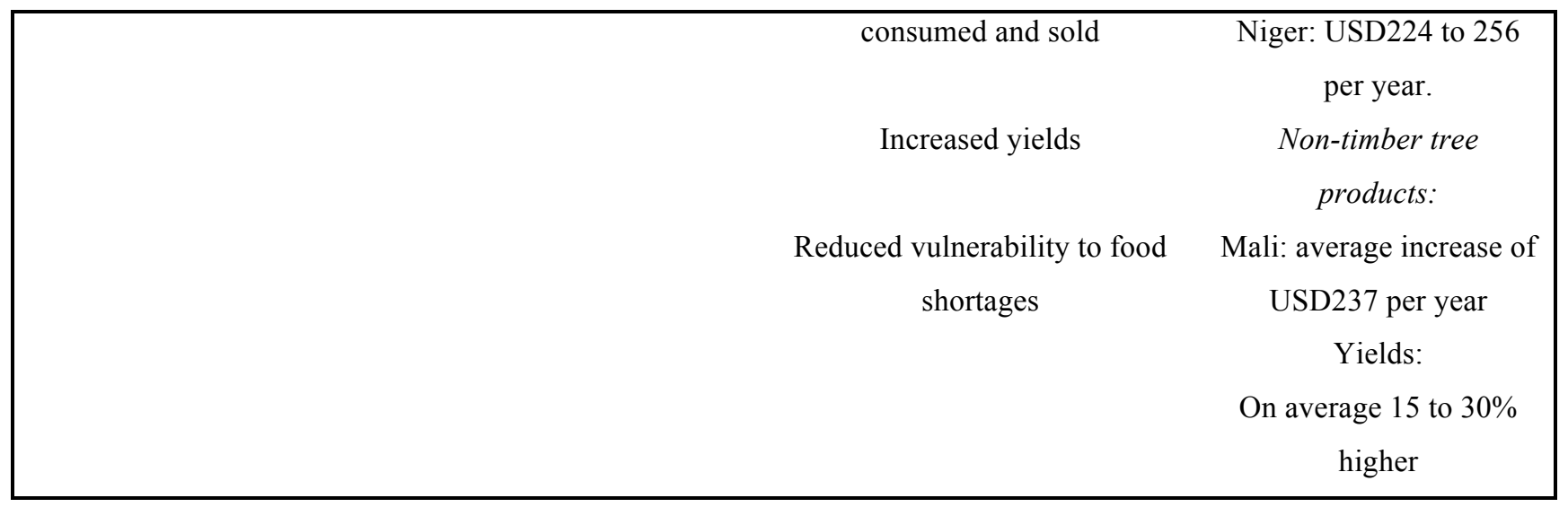

Below, we review the major research conclusions of each of these publications, grouped according to theme.

\section{Theme 1: Increased tree cover}

Tree density and cover has increased substantially in parts of Niger where FMNR was adopted by farmers since the 1980s. Two reports prepared for the U.S. Agency for International Development (USAID) in different parts of Niger were among the first to counter popular perceptions that the Sahel's vegetation was universally degrading (Larwanou et al. 2006; McGahuey and Winterbottom 2007). Based on focus groups, field visits, remote sensing, and other techniques, they suggested that large tracts of Niger's drylands had been regreening over recent decades, with tree cover increasing on millions of hectares due to the adoption of FMNR. The scientific literature appears to confirm the trends. A remote sensing study of vegetation trends in the Sahel overlaid Normalized Difference Vegetation Index (NDVI) and rainfall estimates and suggested that while the climate cycle could explain increase some increased vegetative cover, some nonrainfall related regreening had taken place through the efforts of human management (Hermann et al. 2005). The study points to Niger as a prime example where FMNR was a likely contributor to this phenomenon. Tougiani et al. (2009) report that, in the Aguie department of Niger, after 6 years of a NGO/Government project, farmers had converted 130,000 ha. of treeless land to FMNR, containing between 103 and 122 trees/ha. Larwanou and Saadou (2011), based on a tree vegetation inventory, suggest that FMNR had increased biodiversity and availability of harvestable timber: they state that "in all sites, it was obvious that wood shortage ... was alleviated" (Larwanou and Saadou 2011:199). Finally, Sendzimir et al. (2011) develop a dynamic systems model to account for the observed reforestation. Their analysis points to targetted interventions like FMNR, together with political changes like local land management autonomy and a decline in centralised government interference, as the driving forces of 'regreening' within the broader context of a relatively favourable climate cycle (Giannini et al. 2008; Mortimore and Turner 2005). It should be noted that many of the above studies do not distinguish between types of vegetative cover; while FMNR in principle favors native biodiversity the increases in tree cover could in some cases be from single agroforestry trees.. 


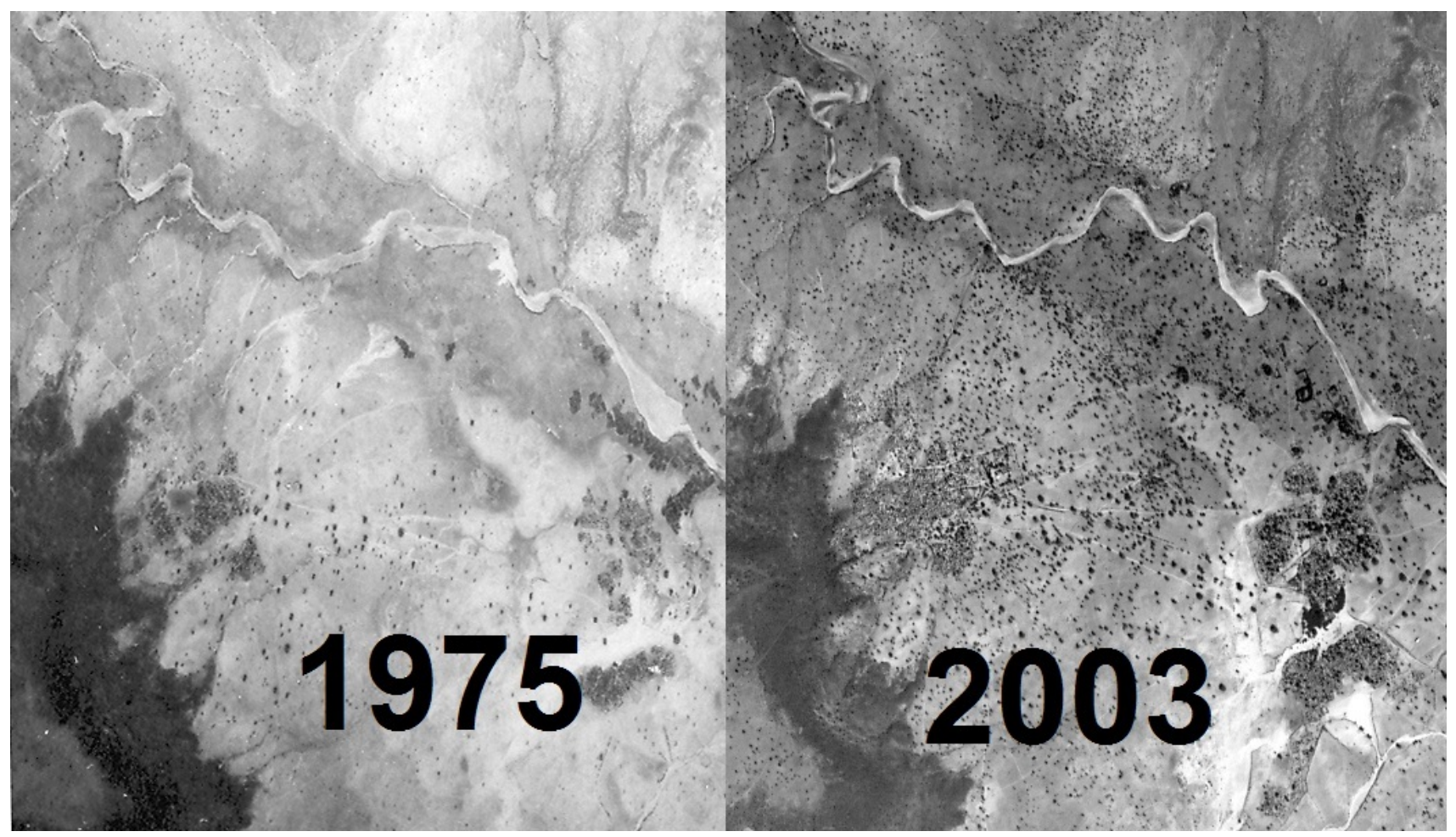

Figure 2: Satellite image of landscape surrounding Galma Village, Niger: Population and Tree cover has increased over 30 years (Courtesy of the U.S. Geological Survey, EROS Center)

\section{Theme 2: Increased crop yields}

Two of the evaluations of FMNR calculated its impact on crop productivity. Comparing FMNR adopting households in Maradi Region to matched non-adopters, Haglund et al. (2011) calculated that the adopters' crop production values were almost 60 percent higher. Place and Binam (2013) found crop yields of FMNR adopters in four West African dryland countries were between 15 to 30 percent higher than non-adopters. In addition, an overview publication (Reij et al. (2009) estimated that the soil restoration effect of FMNR's spread across Niger has resulted in at least 500,000 additional tonnes of grain produced per annum, which they equate to the consumption needs of 2.5 million people.

\section{Theme 3: Household income and local economic value.}

Previous studies imply that adoption of FMNR improves cash incomes through improved agricultural yields and timber sales, as well as through the sale of firewood and of carbon credits. Cunningham and Abasse (2005) provide a case study of the NGO 'Serving In Mission's' (SIM) Maradi Integrated Development Project in Niger that began in 1983. They show that wood sale income for farmers intensively applying FMNR to their land was almost nine times higher than that of non-adopting farmers (Cunningham and Abasse 2005:4). Reflecting on his experiences in that same project, Rinaudo (2012) estimates that a FMNR adopting household would be earning an additional USD 140 per year by rotationally harvesting timber poles from just 40 stumps. Haglund et al. (2011) also focussed original research on the case of Maradi, finding that FMNR adopters earned around 30 percent more income than matched non-adopters. They report that FMNR adopting households reported increased wood supply (98\% of respondents), improved soil fertility (98\%), improved crop yields $(92 \%)$, healthier animals $(81 \%)$, increased revenues $(78 \%)$ and improved food security $(73 \%)$.

Evidence from elsewhere in Africa supports the Maradi case. With native parkland trees contributing strongly to household income in rural areas (Faye et al. 2010), the expansion of tree resources due to FMNR can increase income. 
Place and Binam (2013) demonstrate that FMNR practitioners across four West African countries had higher sales of firewood and non-timber tree products (see Table 1). Sales of FMNR timber and other tree products resulted in participating villages avoiding “...tragedy and reliance on famine relief” (Tougiani et al. 2009:385). Finally, and perhaps most dramatically, in a new development related to the creation of carbon emissions offset markets through the Kyoto Protocol's Clean Development Mechanism, a 2,728 ha. community-managed FMNR site in Ethiopia is forecast to generate around USD 726,000 for the community over the initial 10 years (Brown et al. 2011:329).

\section{What gaps exist in FMNR's evidence-base?}

FMNR is considered useful because it generates livelihood benefits for poor land users. However, livelihood security is not just linked to income, but to a much broader set of relationships, conditions, and physical factors. Livelihood has been described as assets, capabilities and activities to provide a living (Scoones 1998:5), or as 'five capitals': human (skills, knowledge and health), physical (shelter, transportation, energy, and communications), social (including networks, associations, relationships of trust, and access to social institutions), financial (such as savings, access to credit, remittances or pensions) and natural (stock of available natural resources including land, water, forests, indigenous plants, animals and insects) (Haglund et al. 2011; Scoones 1998). The studies reviewed above primarily emphasise financial capital (such as household cash incomes and crop yields) and some aspects of natural capital (especially changes in tree cover). Thus, we may conclude that researchers either have not prioritised non-economic livelihood benefits or have not identified methodological tools to measure such outcomes. Many of the above studies made reference to a wider number of livelihood outcomes, but did not measure their impact (Brown et al. 2011; Cunningham and Abasse 2005; Haglund et al. 2011; Larwanou et al. 2006; Place and Binam 2013). The resultant undervaluing of non-market livelihood benefits of FMNR has been acknowledged by a number of authors (Faye et al. 2010:429; Fifanou et al. 2011:2; Reij and Smaling 2008:417-419). In order to fill this gap and present a more comprehensive measure of the impact of FMNR adoption on sustainable rural livelihoods (Scoones 1998), we used the SROI approach. SROI lays aside predetermined outcome indicators in order to record, quantify and valuate what participating households perceived as of most value to them. In so doing, economic, social, health and environmental impacts of FMNR have been valuated in a way that allows comparison or aggregation despite their intrinsic differences.

\section{TALENSI CASE STUDY AND RESULTS}

\section{Location and context of the project}

The northernmost region of Ghana has a semi-arid tropical dryland climate. Rainfall, which averages $950 \mathrm{~mm}$ per year, is highly variable and concentrated in the period between May and October (Dietz et al. 2004; MoFA 2011). The Upper East administrative division is relatively densely populated, at 200 people $/ \mathrm{km}^{2}$ in some places. The economy is predominantly agricultural, though there are trends of livelihood diversification and migration remittances in response to economic transformations. Important crops include millet, sorghum, maize, rice, groundnuts, and cotton; and livestock such as cattle are also prominent. Longer term trends in land use in northern Ghana include the extension and intensification of farming of bush areas due to population pressure and market opportunities, as well as the increased cultivation of low lying areas, facilitated by tsetse fly eradication, ox plough adoption, and irrigation projects (Dietz et al. 2004; Laube et al. 2012; Yaro 2006). 
In this region, livelihood challenges such as poverty, drought and resource scarcity have been a reality for decades (Agyemang 2012). These challenges have been compounded by land degradation. In the baseline survey for the project we review (detailed below), farmers reported problems of loss of soil fertility, declining yields and reduced availability of wild foods and other natural resources. These assessments are corroborated by other studies (Bugri 2008; Damnyag et al. 2012; Ditto 2009; Wopereis et al. 2006; WVG 2008). These problems were caused by expanding charcoal production, logging and agriculture, the loss of traditional long fallow periods, and lack of tree ownership rights. Recovery of natural resources was hampered by bushfires, and traditional beliefs that discouraged planting of trees: specifically, the belief that planting a tree was akin to defying Nature, and would result in death (Agyemang 2012; Bugri 2008; Weston and Hong 2013b).

Figure 3: Location map of study site.

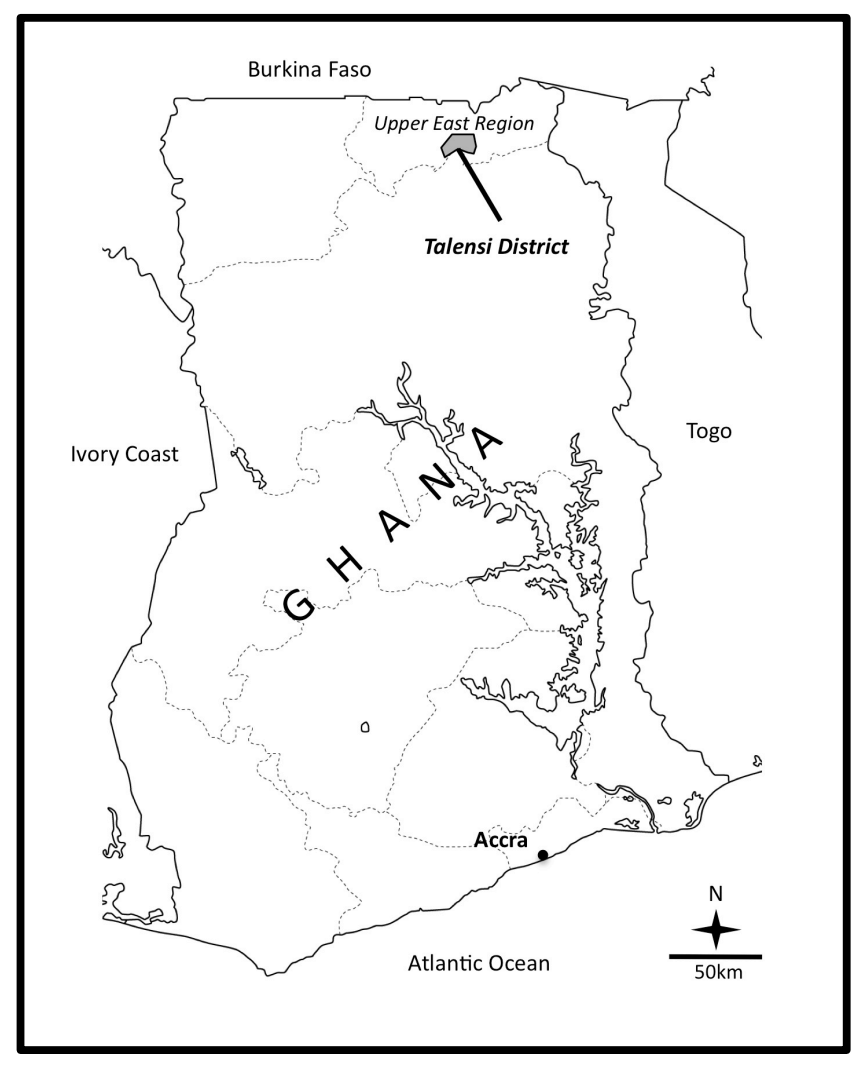

To reverse this situation of resource degradation, the humanitarian and development NGO World Vision implemented an FMNR project in the Talensi District ${ }^{1}$ in the Upper East Region of Ghana, bordering Burkina Faso (Figure 3). Talensi District covers around $500 \mathrm{~km}^{2}$, of which around 27,000 ha is cultivated (WVG 2008). The project started in July 2009 and ran for three years. It worked with nine out of the district's 69 communities, containing a population of 11,920 in 1,472 households (Weston and Hong 2013b).

\footnotetext{
${ }^{1}$ Previously 'Talensi-Nabdam' District, which was divided into two separate districts in 2012. Note also that the area was the site of well-known ethnographic work by Meyer Fortes in the 1930s (Parker 2013).
} 
The Talensi FMNR project promoted the restoration of multi-purpose trees in two different landscape forms: farmland and community-managed forests. Farmlands are family-owned crop fields under a customary tenure system, averaging 1.3 hectares per family (Weston and Hong 2013b). Community-managed forests are protected by community by-laws and managed by community members who benefit from harvesting wood, grasses and other resources. The promotion of FMNR was complemented with training on anti-erosion techniques, bulk composting, field mulching, suppression of bushfires and field burning, fuel efficient wood stoves, formation of income-generating groups, and formation of savings groups (Weston and Hong 2013b). The project also facilitated the planting of 40,000 fruit trees. Extension was carried out via the formation of community FMNR Groups, made up of each community's most dynamic farmers. These 'lead farmers' (90 men and 90 women) were trained in FMNR practices and were pivotal in mobilizing other community members to learn and experiment (Weston and Hong 2013b).

A small number of other organisations had provided some agricultural assistance to the communities in the past. In previous years, the NGOs 'Action Aid' and 'Techno-Serve' had delivered short-term assistance in the form of donated agricultural inputs. One private national firm is providing some philanthropic support to the farming community through donated tree seedlings. The Ministry of Food and Agriculture (MoFA) is also active in the area, but charges a fee-forservice for many of their supports, such as tractor ploughing, seeds and mineral fertiliser, which must be repaid at harvest time.

The end-of-project evaluation (Weston and Hong 2013b) found that community members used FMNR to restore 161 hectares of community-managed forest (with an average density of 2,343 trees/ha) and 336 ha of crop land (with an average tree density of 57 per ha.). These contrast with baseline tree density in both lands of 5 trees/ha. These managed forests now contain around 567,000 trees of which 377,000 can be counted as additional due to the project. On farmland, 547 households, or 37 percent of all households, adopted FMNR in their crop fields. Focus groups consistently estimated that, even the trees previously in the area would have disappeared within five to six years in the absence of the project. Reforestation on forest and farmland was reinforced by the project's mobilisation of community volunteer fire brigades. These collective efforts to suppress fires created time for regrowth to reach grassfire resistant heights (Darkoh 2003; Samaké et al. 2005). In a survey of FMNR adopters, 94 percent reported an increase in soil fertility (against 26 percent among the comparison group); 66 percent reported improvement in soil erosion (against 17 percent in the comparison group); and 46 percent thought that the FMNR practices had generated more wild food (fruits, nuts, rabbits and partridges). The evaluation documented that 157 households have adopted fuel efficient stoves (90 were distributed by the project and the remainder were spontaneous adoptions), and that 42 percent of all FMNR lead farmers and 10 percent of neighboring households learned and adopted the improved, bulk compost method (over 94 percent of those who learned the technique went on to apply it to their farmlands). Finally, in terms of natural resources, the annual field surveillance (Akpalu 2012), focus group discussions, and household survey (Weston and Hong 2013b) also documented that the return of natural tree coverage increased overall biodiversity.

Figure 4: Comparison photos of hill overlooking Yameriga village. 


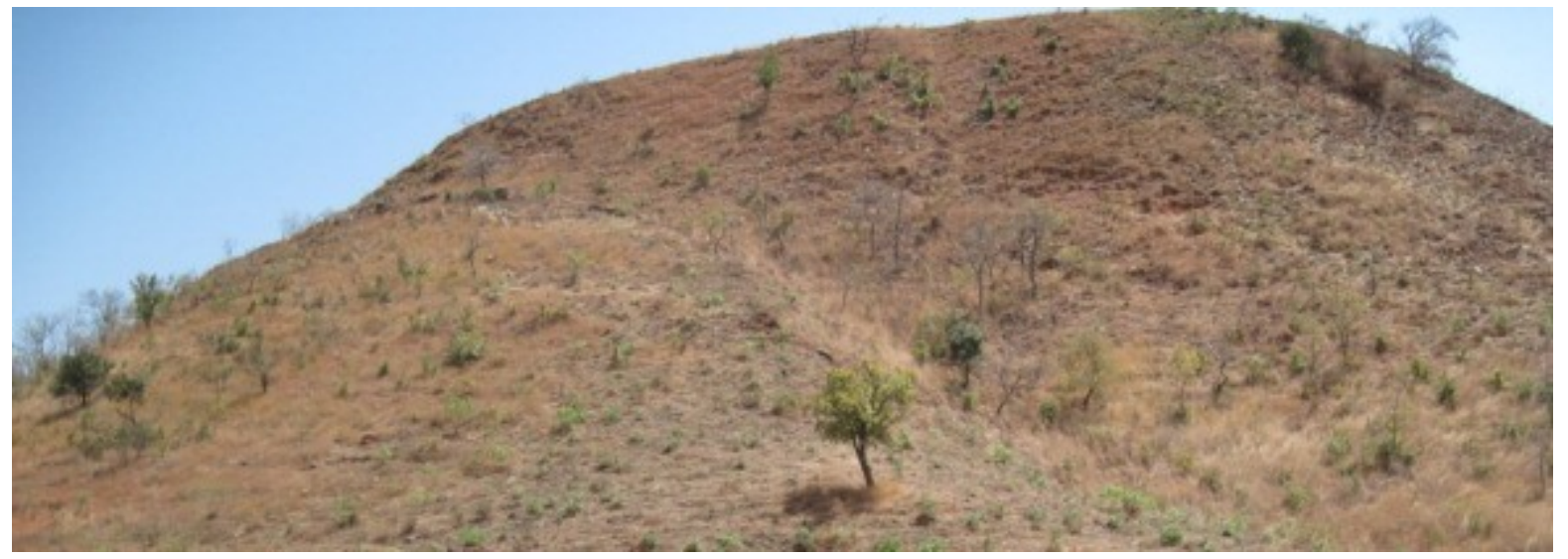

Figure 4a: February 2010. (Photo: Paul Akaribo, WV Ghana)

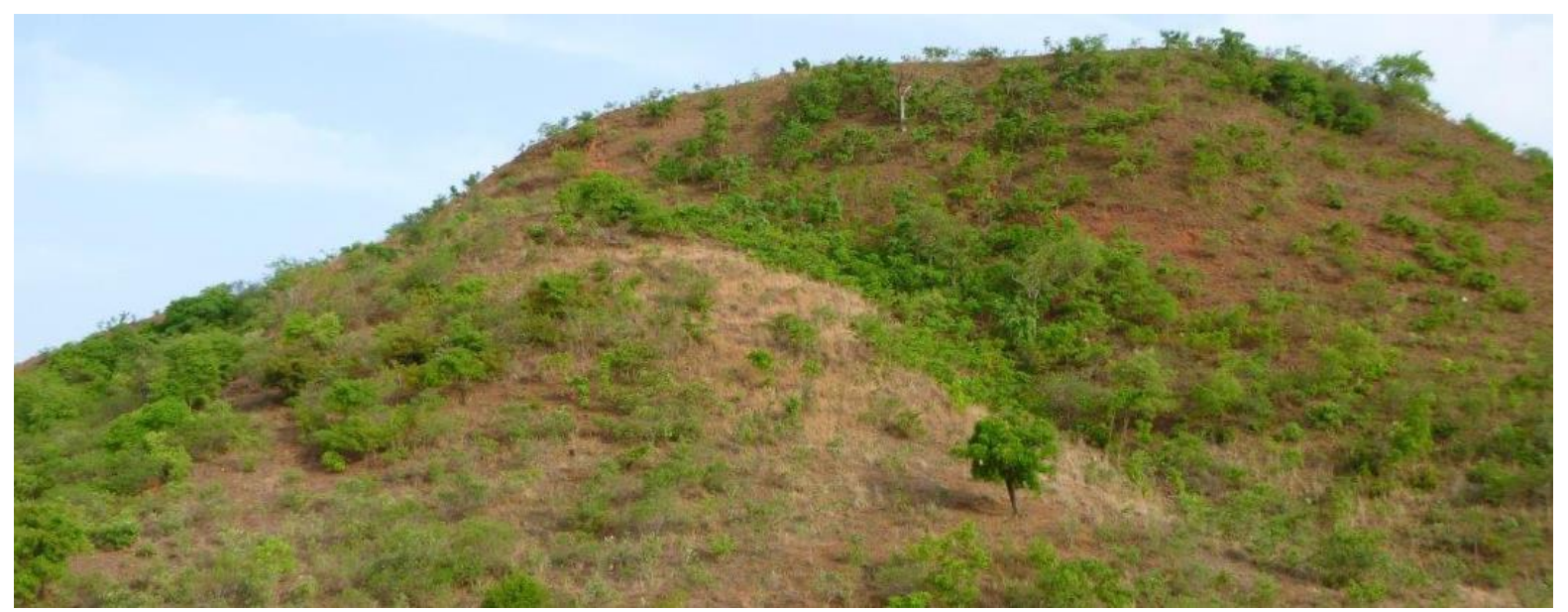

Figure 4b: April 2014. (Photo: Anne Crawford, WV Australia)

\section{SROI Analysis of Project Inputs and Outcomes}

The Social Return on Investment Analysis estimated proxy monetary values for the social benefits of the FMNR project, many of which are non-market outcomes that have no direct economic measure. It compares project inputs against outcomes.

Regarding project inputs, World Vision Australia funded activities using private donations and a grant from the Australian Government. USD 306,392 covered all costs associated with World Vision Ghana staff time, material inputs and contractors. Australian technical and monitoring support was valued at approximately USD $17,424 .^{2}$ We calculated the value of in-kind contribution from Talensi community members to be approximately USD 90,871. Each of the 180 lead farmers contributed an average of 78 volunteer days per year, some for 2 years, some for 3 years. 315 community members contributed time as fire brigade volunteers. This time was valued in terms of the district's average adult laborers' daily wage of GHф 4 (USD2.1). Thus the total value of project inputs was USD 414,686.

The value of project outcomes was based on data collected in focus group discussions and the household survey. The benefits identified by the community participants and their calculated values are presented in Table 2. Some additional project outcomes were mentioned by stakeholders but not included in the SROI calculation. This was due to lack of

\footnotetext{
${ }^{2}$ Finance figures sourced from World Vision Australia financial database and timesheet records
} 
identifiable quantifiable or proxy value. These outcomes include, on the positive side, a reduction of time required by boys to herd cattle and, therefore, freed to attend classes or recreation; women's increased participation in educational activities and attending to their families' health due to time saved from collecting firewood; and the protective effect of trees reducing damaging wind speeds and storm impacts. A negative outcome that was raised but not incorporated was an increased fear of snake bites while pruning shrubs. This concern was raised by nine percent of lead households in the survey, but no actual bites were recorded and the concern did not appear to result in changed behaviour.

Table 2: Outcomes per stakeholder group and their proxy financial values

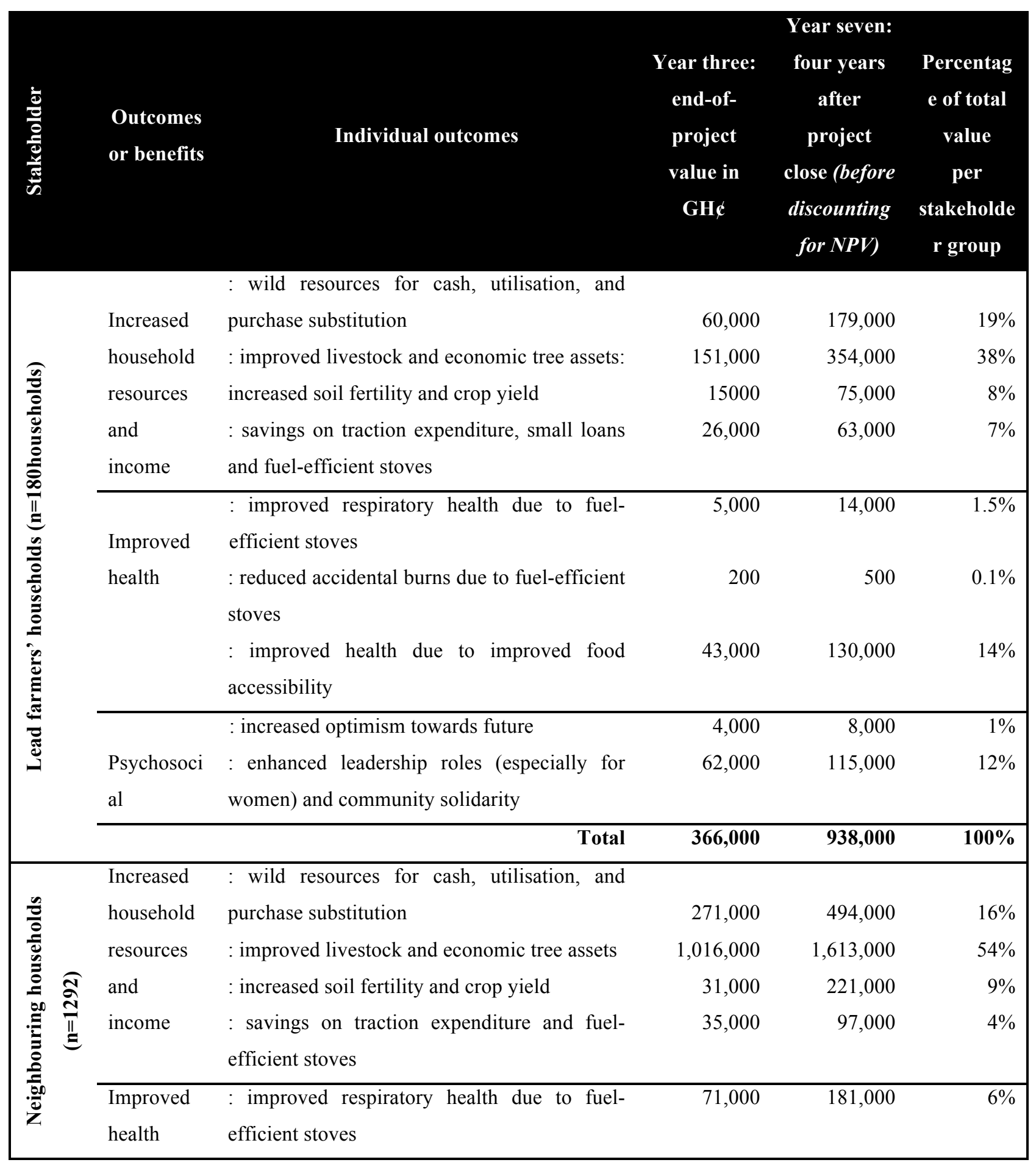




\begin{tabular}{|c|c|c|c|c|c|}
\hline & & $\begin{array}{l}\text { : reduced accidental burns due to fuel-efficient } \\
\text { stoves } \\
: \text { improved health due to improved food } \\
\text { accessibility }\end{array}$ & 70,000 & 210,000 & $0.1 \%$ \\
\hline & $\begin{array}{l}\text { Psychologi } \\
\text { cal }\end{array}$ & $\begin{array}{l}\text { : increased optimism towards future } \\
: \text { enhanced leadership roles and community } \\
\text { unity. }\end{array}$ & $\begin{array}{l}18,000 \\
47,000\end{array}$ & $\begin{array}{r}46,000 \\
105,000\end{array}$ & $\begin{array}{r}1.5 \% \\
4 \%\end{array}$ \\
\hline & & Total & $1,561,000$ & $2,969,000$ & $100 \%$ \\
\hline \multirow{9}{*}{ 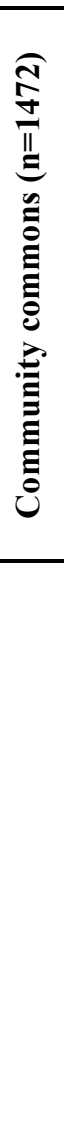 } & Economic & : tree stock assets for community & $1,607,000$ & $6,512,000$ & $84 \%$ \\
\hline & $\begin{array}{l}\text { Psychologic } \\
\text { al }\end{array}$ & $\begin{array}{l}\text { : change in attitudes toward environmental } \\
\text { protection } \\
\text { : more beautiful and comfortable existence }\end{array}$ & 58,000 & $\begin{array}{l}174,000 \\
477,000\end{array}$ & $2 \%$ \\
\hline & $\begin{array}{l}\text { (Global) } \\
\text { environment } \\
\text { al }\end{array}$ & $\begin{array}{l}\text { : reduction in carbon dioxide through fuel- } \\
\text { efficient stoves } \\
: \text { carbon dioxide sequestration through } \\
\text { reforestation }\end{array}$ & 75,000 & 619,000 & $0.2 \%$ \\
\hline & & Total & $1,907,000$ & $7,803,000$ & $100 \%$ \\
\hline & & Grand total of value created $(2012 \mathrm{GH} \phi)$ & $\begin{array}{l}3,835,000 \\
\text { (US\$ 2m) }\end{array}$ & $11,710,000$ & \\
\hline & & & & $\begin{array}{r}=10,304,000 \\
(\mathrm{US} \$ 5.5 \mathrm{~m}) \\
\text { net present } \\
\text { value }\end{array}$ & \\
\hline & & Value of all inputs (GHc) & $\begin{array}{r}779,808 \\
\text { (US\$ }\end{array}$ & $\begin{array}{r}779,808 \\
\text { (US\$ }\end{array}$ & \\
\hline & & SROI ratio & $414,686)$ & $414,686)$ & \\
\hline & & & $1: 5$ & $1: 13$ & \\
\hline
\end{tabular}

By the end of the project, GH\& 3,835,000 (USD 2 million) of value had been created. Assuming that the FMNR techniques becomes more widely shared, as has happened in FMNR experiences cited earlier, and estimating the number of trees expands by 16 per cent per year, which is very conservative compared to the Niger experience (Reij et al. 2009; Rinaudo 2012) the project is forecast to generate GH $\phi$ 10,304,000 (USD 5.5 million) of net present value by 2016. The net social return on direct investment by World Vision, after accounting for discounting factors, is thus, a social return on investment ratio of 6:1 by the end of the project, 17:1 four years after the project, and 43:1 ten years after project closure. When we factor in the value of in-kind contributions, the SROI ratios become 5:1, 13:1, and 34:1, respectively.

\section{Sensitivity Analysis}

SROI calculation places emphasis on avoiding the risk of over-claiming by erring on the side of undervaluing estimations (Nicholls et al. 2012). Nevertheless, calculations based on estimations and subjectivity of participants are prone to error. A sensitivity analysis was conducted to test the robustness of the SROI ratio by testing the effect of certain variables, 
such as the magnitude of discounting factors and the valuation given to important outcomes (Table 3). By running various scenarios, we found that the three ratios (end-of-project, four years after project and 10 years after project) had low sensitivity to changes in individual discounting factors. Discounting factors such as deadweight or attribution had to be increased to 80 percent before the social return approached a 1:1 ratio. The most sensitive variable was the value of timber stored in the additional young trees.

Table 3: Effect of various calculation adjustments upon the SROI ratio, to test the sensitivity of results (Weston and Hong 2013a)

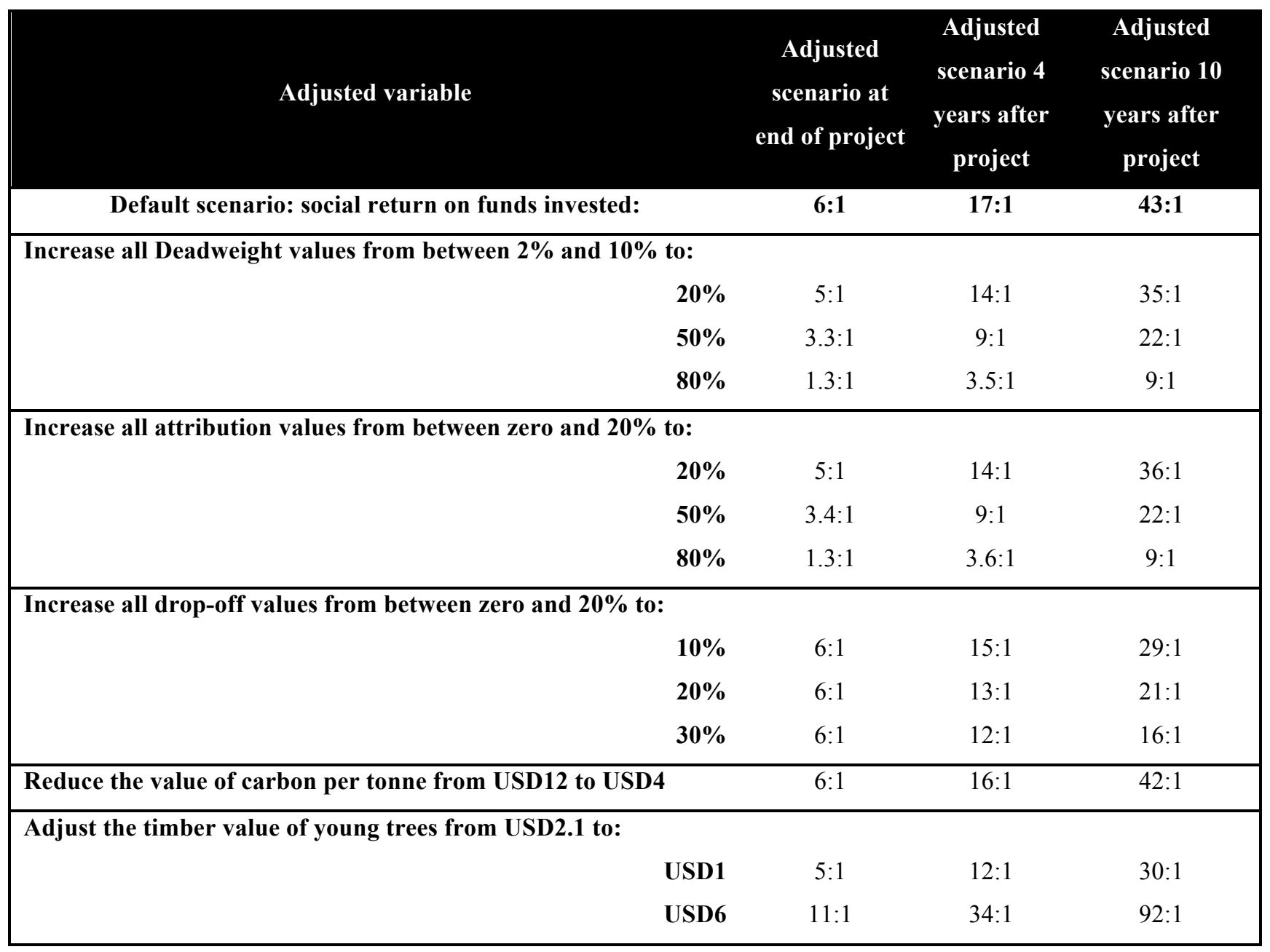

Inclusion of the atmospheric benefit of regrowing trees may be questioned by some who might argue the benefit is too indirect to the target community, or that double-counting has taken place by recording the latent timber value of the trees as an asset and the carbon sequestered by the same trees. We argue that the inclusion is legitimate for three reasons: the scientific reality of the carbon removal from the atmosphere; project participants' testimonies of the positive value of knowing their trees are making a healthier atmosphere; and that the same trees provide two distinct benefits of timber income and carbon sequestration (if the timber is not burnt it continues to stock carbon). However, we also ran a sensitivity analysis to see what happens when carbon sequestration and emission reductions from fuel-efficient stoves are removed. Under this scenario, the social return on investment four years after project closure decreases from 17:1 to 16:1, and the immediate (end-of-project) remained relatively unchanged at $6: 1$. 


\section{Value created by the FMNR project per household}

SROI was developed to measure the magnitude of community benefit against project inputs, not to communicate a project's or technology's contribution to individual households' wellbeing. Yet, the nature of the data analysis lends itself to interpreting the average value of benefit accrued by households of different stakeholder groups. The SROI calculation estimated the total value of social, health, environmental and economic benefits for 180 lead farmer households to be $\mathrm{GH} \notin 366,000$ at the end of project, $\mathrm{GH} \phi 938,000$ four years hence, and $\mathrm{GH} \phi 1,826,000$ ten years hence. To these direct benefits we may add a pro-rata proportion of the community commons benefits. This brings the aggregate value generated by the project for lead households collectively to GH $₫ 599,193$ at the end of project and GH $\$ 2,386,071$ four years hence. Therefore, by the end of the project, the value created per household equates to GH $\$ 3328$ over two years or GH $\notin 1,664$ (USD887) per year. Applying the same formula to neighboring households arrives at a created value of GH $\notin 1,228$ (USD 654) per household per year. These values to households are substantial in a country where the gross national income per capita is USD 1,410 (World Bank 2013).

\section{DISCUSSION}

To date, research on FMNR has emphasized economic incomes and agricultural yield values. This case study contributes additional evidence that supports these claims. However, this case study also found that, as far as participating households are concerned, increased incomes and crops yields are not the most important benefits of adopting FMNR. In lead, neighbor and community commons stakeholder groups, the most valuable change was the increase in value of assets in the form of tree stocks and livestock. The livelihood implication of these benefits come from their contribution to household resilience against periodic shocks (Thorlakson and Neufeldt 2012; Walker et al. 2006). Shade and perennial sources of leaf and grass fodder have made livestock more resilient in the dry season. The increase in tree cover on each managed plot has increased households' stocks of 'timber' assets that can be monetized in difficult times, and can be replenished later by regrowing (Figure 5).

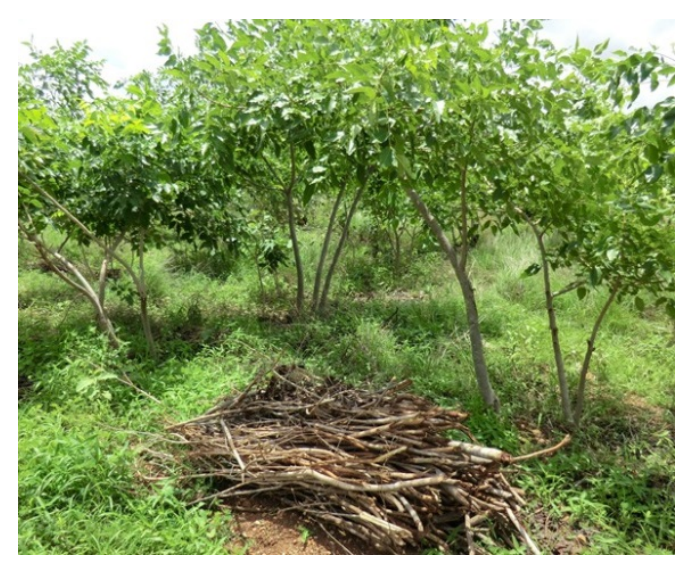

Figure 5: Yameriga village. Firewood bundled next to one-year-old FMNR regrowth in community-managed forest (photo: Lead author)

The second greatest change for both lead and neighboring households was the increase of consumable wild resources: especially wild foods (plant and animal) and construction materials (timber poles and thatch for fencing and roofing). Some association exists between increased wild resources and incomes, with households describing the sale of some wild products, like shea fruit (Figure 6). However, for the most part, the main value was in the form of consumables at 
household level that never entered the cash economy. This finding is consistent with the point that, especially in drylands, populations that retain access to wild food plants fare best in times of drought (Darkoh 2003). Closely associated with these benefits is the stated health benefits related to increased and diversified diets (Golden et al. 2011; Jamnadass et al. 2011; Powell et al. 2011).

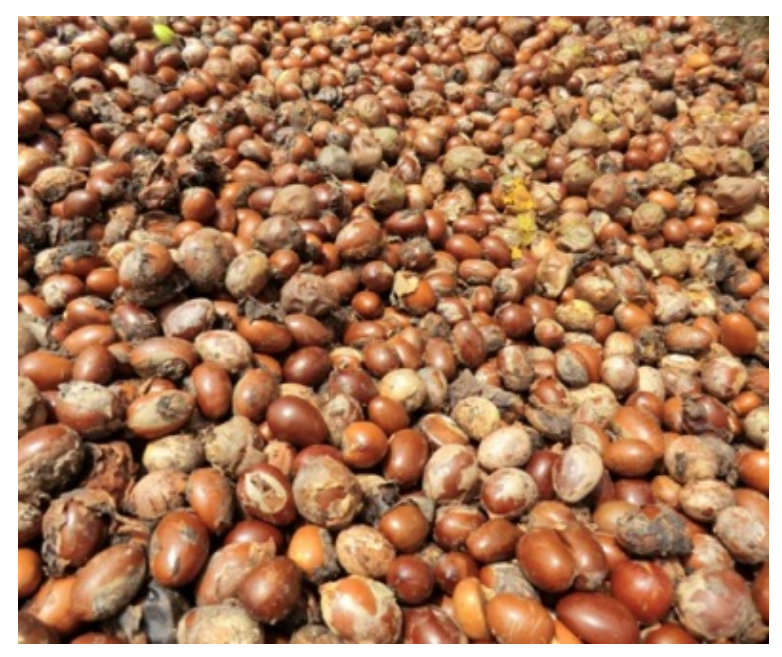

Figure 6: Shia village. Shea nuts harvested for processing into butter (Photo: lead author)

The third most significant improvement perceived by target stakeholders is a cluster of psycho-social benefits consisting of joy and peace-of-mind from the enhanced beauty and comfort of the now greener landscape, enhanced leadership confidence and experience for women and men who took part in FMNR groups, improved attitudes towards environmental management, and greater optimism for the future of their farms and communities (Figure 7). Literature related to climate change adaptation suggests that, whereas environmental degradation has a major negative effect on people's mental wellbeing (Fritze et al. 2008; Maginness and Stephens 2008) and stifles cognitive ability to adapt to changing economic and climatic conditions (Van Haaften and Van der Vijver 2003), hope gives rise to optimism, which gives rise to better mental health and a greater mental energy to pursue adaptation (Fritze et al. 2008). Presenting viable and affordable adaptation options, such as FMNR, markedly improves cognitive ability to cope with such stresses (Grothmannn and Patt 2005). Furthermore, according to the focus groups, community collaboration necessary to share FMNR farmer-to-farmer and to establish collective protocols among land users improved social capital in Talensi, which can also enrich and secure the livelihoods of individual households (Collier 1998; Woolcock 1998). 


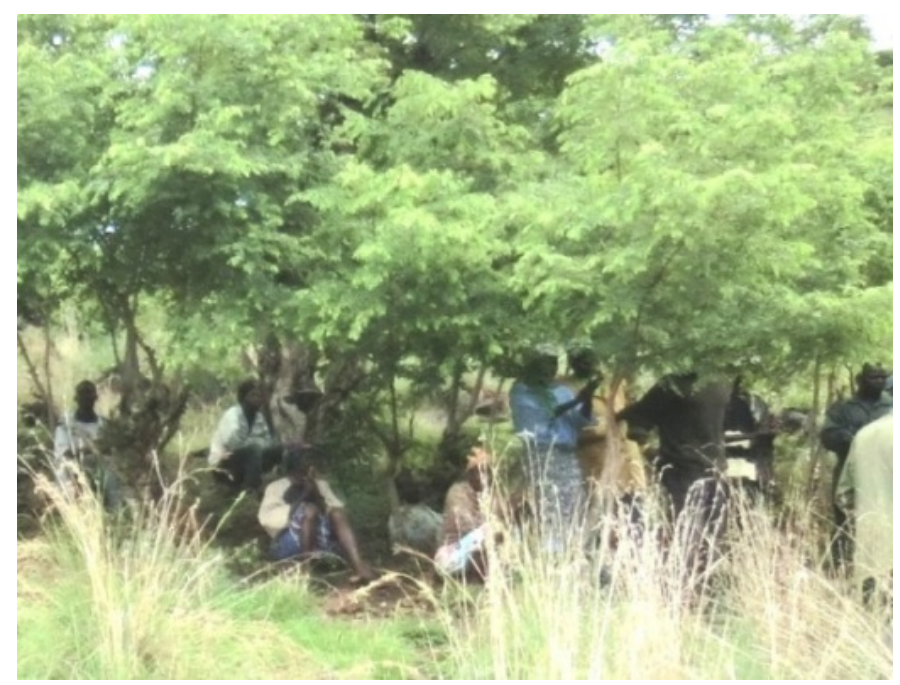

Figure 7: Wakii village. Residents shade from afternoon sun in community-managed FMNR reserve (photo: lead author).

The value of outcomes calculated in Talensi District using SROI is consistent with findings elsewhere. Haglund et al. (2011) calculated increases in crop yield and diversity and timber production from FMNR adoption in Maradi Region, Niger, 20 years after the introduction of FMNR is between USD 17 and 21 million per year. Taking into consideration that the effects of FMNR in Talensi are early and have not yet spread widely beyond the target communities, these magnitudes seem consistent with our finding of USD 2 million at the end of the project. At the household level, Haglund et al. (2011) calculated that FMNR-adopting householders in Niger are earning around USD 51 per year more in crop yields, and Place and Binam (2012) estimate that from firewood sales earn FMNR adopters in West African drylands up to an additional USD 256 per year. Therefore, combined, we might assume that, in Sahelian West Africa, FMNR adopters are up to USD300 better off on strictly economic terms. The Talensi SROI calculation found that asset accumulation, increased consumption of wild products, increased health and psycho-social benefits as well as yield and income were worth USD 655 to 887. The overall Talensi SROI calculation found that non-economic outcomes added more value than changes in income and yields. Therefore, a total estimate of all benefits that is two to three times higher than incomes estimated by other studies appears consistent also. We should bear in mind that we cannot make a pure comparison between studies. The Ghanaian economy is growing faster and average prices likely to be higher than in Niger. The Talensi FMNR project promoted not only the FMNR technique, but other complementary sustainable agricultural techniques that are likely to have contributed to outcomes, particularly for direct participant households.

\section{CONCLUSION}

Previous studies on FMNR make claims about diverse social, health and environmental as well as economic benefits. Yet, to date, all published original research has focussed on economic indicators, and/or tree-counting as an assumed contribution to human wellbeing. Some studies have described other benefits, though have not quantified their values. Thus, to date, no study has provided a measure of the aggregate livelihood impact of community adoption of FMNR. This study has attempted exactly this by documenting and valuating what outcomes were of perceived importance by stakeholder households of a FMNR project. SROI methodology was used to identify proxy financial values for each outcome and these outcomes were aggregated to calculate the total value created in target communities by the project. The study found that the social return on investment more than compensated for project costs and in-kind contributions. 
This study gives us a clear understanding and measure of the diversity of livelihood impacts that FMNR adoption can contribute to vulnerable rural communities in dryland zones of Africa. The study validated the importance of economic outcomes of increased crop yields and incomes found by previous studies. However, non-market benefits were found to generate greater value to stakeholder households. For the Talensi community in Upper East Region of Northern Ghana, the most valuable outcome categories were: 1) increased assets in the form of tree stocks and improved livestock; 2) increased wild resources (especially wild foods and construction inputs) for household consumption and sale, and associated dietary health benefits; 3) improved psycho-social wellbeing as a result of a more aesthetically pleasing and comfortable community and work environment, enhanced leadership capacity of FMNR group members, and a more positive outlook; and 4) improved soil fertility and crop yields. The value of carbon sequestered by increased tree cover was also identified by stakeholders as important and validated by carbon calculations, which contributed to the overall value created by the FMNR project.

Estimating the livelihood impact per household revealed that the social, health, environmental and economic values created by this FMNR project were between USD655 and USD887 per annum. These figures are two to three times greater than other studies' calculations that are based only on the economic returns of FMNR. This is consistent with this study's finding that non-economic outcomes generated more value than the economic benefits of the project. This highlights that, though FMNR is often introduced on the grounds of improving arable soils for crop production, such gains may be secondary to the livelihood contribution of natural assets and consumables restored to the landscape.

The project's outcomes were the result of FMNR adoption, landscape fire suppression and the promotion of complementary sustainable agricultural techniques. This serves to emphasise that, while FMNR is a field and forest restoration technique, the concept is also an embodiment of rural landscape management that empowers land users and creates space for ecological dynamics to restore soil and natural resources. Across Africa, as well as many other regions of the world, agricultural land and production is threatened by erosion, soil depletion and loss of biodiversity. If African agriculture is to adequately feed future generations, it must not only increase productivity, but also restore already degraded lands and reduce small-scale farmers' exposure to climatic vulnerability. FMNR is a valid contribution to achieving these objectives.

\section{Acknowledgements}

This research arose from a World Vision project evaluation subsequently elaborated into an academic study at Monash University. It was made possible by the support of World Vision and its donors. World Vision Australia's Lucia Boxelaar and Tim Morris kindly made internal resources and data available for publication; World Vision Ghana staff facilitated data collection support. At the time of data collection and analysis, Mr Weston and Dr Kaboré were employees of World Vision Australia. The Talensi FMNR Project was funded by the Government of Australia and private donations from the Australian public. We gratefully acknowledge the willing participation of Talensi community members, and the inputs of Tony Rinaudo, as well as satellite imagery provided by Gray Tappan of the US Geological Survey EROS Center. Social Ventures Australia helped develop semi-structured question guides. The manuscript benefited from comments by Craig Thorburn, Bruce Missingham, and two anonymous reviewers. 


\section{REFERENCES}

Agyemang I (2012) Assessing the driving forces of environmental degradation in Northern Ghana: Community truthing approach. Afr J Hist Cult 4:59-68

Akpalu SE (2012) Report on the monitoring of farmer managed natural regeneration (FMNR) sites in the Talensi District. Forestry Research Institute Of Ghana, Savannah Research Centre, Bolgatanga, Upper East, Ghana,

Bader J, Latif M (2011) The 1983 drought in the West Sahel: a case study. Clim Dyn 36:463-472.

Bae K, Lee D, Fahey T, Woo S, Quaye A, Lee Y-K (2013) Seasonal variation of soil respiration rates in a secondary forest and agroforestry systems. Agroforest Syst 87:131-139.

Brechears D, Whicker J, Zou C, Field J, Allen C (2009) A conceptual framework for dryland aeolian sediment transport along the grassland-forest continuum: effects of woody plant canopy cover and disturbance. Geomorphol 105:28-38

Brown DR, Dettmann P, Rinaudo T, Tefera H, Tofu A (2011) Poverty alleviation and environmental restoration using the clean development mechanism: a case study from Humbo, Ethiopia. Environ Manag 48:322-333 doi:10.1007/s00267-010-9590-3

Bugri J (2008) The dynamics of tenure security, agricultural production and environmental degradation in Africa: evidence from stakeholders in North-East Ghana. Land Use Policy 25:271-285

CILSS, FAO, FEWSNET, WFP (2012) Avis conjoint sur la situation alimentaire et nutritionnelle au Sahel et en Afrique de l'Ouest. Permanent Inter-State Committee for Drought Control in the Sahel, UN Food and Agriculture Organisation, UN World Food Program, Famine Early Warning System Network. Abdijan, Ivory Coast

Colchester M (1993) Colonising the rainforests: the agents and causes of deforestation. In: Colchester M, Lohmann L (eds) The struggle for the fate of the forests. Zed Books, London

Collier P (1998) Social capital and poverty: Social Capital Initiative Working Paper .no. 4. World Bank Social Development Family, Environmentally and Socially Sustainable Development Network, Washington DC

Cunningham P, Abasse T (2005) Reforesting the Sahel: Farmer managed natural regeneration. In: Kalinganire A, Niang A, Koné B (eds) Domestication des espèces agroforestières au Sahel: situation actuelle et perspectives. ICRAF Working Paper no. 5. World Agroforestry Centre, Nairobi, pp 75-80

Damnyag L, Saastamoinen O, Appiah M, Pappinen A (2012) Role of tenure insecurity in deforestation in Ghana's high forest zone. For Policy Econ 14:90-98

Darkoh M (2003) Regional perspectives on agriculture and biodiversity in the drylands of Africa. Journal of Arid Environments 54:261-279

Dietz T, Millar D, Dittoh S, Obeng F, Ofori-Sarpong E (2004) Climate and livelihood change in North East Ghana. In: Dietz AJ, Ruben R, Verhagen A (eds), The impact of climate change on drylands. Kluwer Academic Publishers, Dordrecht, pp 149-172

Ditto S (2009) FMNR project baseline evaluation report, Rudema Consulting, unpublished

FAO (2009) The special challenge for Sub-Saharan Africa, How to feed the world 2050 - High-level expert forum, 12-13 October 2009, Rome.

Faye MD, Weber JC, Mounkoro B, Dakouo J-M (2010) Contribution of parkland trees to farmers' livelihoods: a case study from Mali. Dev Pract 30:428-434 
Fifanou VG, Ousmane C, Gauthier B, Brice S (2011) Traditional agroforestry systems and biodiversity conservation in Benin (West Africa) Agroforest Syst 82:1-13

Franzel S (1999) Socioeconomic factors affecting the adoption potential of improved tree fallows in Africa. Agroforest Syst 47:305-321

Fritze JG, Blashk GA, Burke S, Wiseman J (2008) Hope, despair and transformation: Climate change and the promotion of mental health and wellbeing. Int J Ment Health Syst 2:13

Garrity D, Akinnifesi F, Ajayi O, Weldesemayat S, Mowo J., Kalinganire A, Larwanou M. \& Bayala J (2010) Evergreen agriculture: a robust approach to sustainable food security in Africa. Food Secur, 2:197-214.

Giannini A, Biasutti M, Verstraete MM (2008) A climate model-based review of drought in the Sahel: Desertification, the re-greening and climate change. Glob Planet Change 64:119-128

Golden CD, Fernald LCH, Brashares JS, Rasolofoniaina BJR, Kremen C (2011) Benefits of wildlife consumption to child nutrition in a biodiversity hotspot. PNAS 108:19653-19656

Grothmannn T, Patt A (2005) Adaptive capacity and human cognition:The process of individual adaptation to climate change. Glob Environ Change 15:199-213

Haglund E, Ndjeunga J, Snook L, Pasternak D (2011) Dry land tree management for improved household livelihoods: Farmer managed natural regeneration in Niger. J Environ Manag 92:1696-1705

Hermann SM, Anyamba A, Tucker CJ (2005) Recent trends in vegetation dynamics in the African Sahel and their relationship to climate. Glob Environ Change 15:394-404

IMF (2012) World Economic Outlook: Coping with high debt and sluggish growth. October 2012. International Monetary Fund. https://www.imf.org/external/pubs/ft/weo/2012/02/. Accessed 5 Feb 2013

Jamnadass RH, Dawson IK, Franzel S, Leakey RRB, Mithöfer D, Akinnifesi FK, Tchoundjeu Z (2011) Improving livelihoods and nutrition in sub-Saharan Africa through the promotion of indigenous and exotic fruit production in smallholders' agroforestry systems: a review. Int For Rev 13:338-354

Kabore C (2010) Community managed natural regeneration Forest project in Humbo Area Development Program. midterm evaluation report. World Vision Australia, Unpublished

Larwanou M, Abdoulaye M, Reij C (2006) Etude de la regeneration naturelle assistée dans la Région de Zinder (Niger): une première exploration d'un phénomène spectaculaire. International Resources Group (IRG), for the US Agency for International Development (USAID), Washington DC

Larwanou M, Saadou M (2011) The role of human interventions in tree dynamics and environmental rehabilitation in the Sahel zone of Niger. J Arid Environ 75:194-200

Laube W, Schraven B, Awo M (2012) Smallholder adaptation to climate change: dynamics and limits in Northern Ghana. Clim Change 111:753-774.

Leakey RR, Tchoundjeu Z, Schreckenberg K, Shackleton SE, Shackleton CM (2005) Agroforestry tree products (AFTPs): targetting poverty reduction and enhancing livelihoods. Int J Agric Sustain 3:1-23

Lingane A, Olsen S (2004) Guidelines for social return on investment. Calif Manag Rev 46:116-135

Maginness A, Stephens M (2008) Managing the impact of climate change in rural communities. Australian Psychological Society InPsych. http://www.psychology.org.au/inpsych/climate_rural/. Accessed 15 June 2013

McGahuey M, Winterbottom R (2007) Transformational development in Niger. January. - USAID and International Resources Group FRAMEWeb. http:/www.frameweb.org/adl/en-US/2803/file/336/Niger.pdf. Accessed 21 April 2013 
MoFA (2011) Talensi-Nabdam: Physical and natural environment. Ministry of Food and Agriculture, Republic of Ghana. http://mofa.gov.gh/site/?page_id=1658. Accessed 1 May 2013

Montpellier Panel (2013) Sustainable intensification: a new paradigm for African agriculture. Agriculture for Impact, Imperial College, London

Mortimore M (1998) Roots in the African dust: Sustaining the Sub-Saharan Drylands. Cambridge University Press, Cambridge

Mortimore M, Turner B (2005) Does the Sahelian smallholder's management of woodland, farm trees, rangeland support the hypothesis of human-induced desertification? J Arid Environ 63:567-595

Moseley WG, Carney J, Becker L (2010) Neoliberal policy, rural livelihoods, and urban food security in West Africa: A comparative study of The Gambia, Côte d'Ivoire, and Mali. PNAS 107: 5774-5779

Nicholls J, Eilis L, Neitzert E, Goodspeed T (2012) A guide to social return on investment. 2 edn. The SROI Network, London

Parker J (2013) The dynamics of fieldwork among the Talensi: Meyer Fortes in northern Ghana, 1934-7. Afr 83:623-645

Place F, Binam JN (2013) Economic impacts of farmer managed natural regeneration in the Sahel: end of project technical report. Free University Amsterdam, International Fund for Agricultural Development (IFAD) Rome,

Place F, Roothaert R, Maina L, Franzel S, Sinja J, Wanjiku J (2009) The impact of fodder trees on milk production and income among smallholder dairy farmers in East Africa and the role of research. World Agroforestry Centre, Nairobi

Powell B, Hall J, Johns T (2011) Forest cover, use and dietary intake in the East Usambara Mountains, Tanzania. Int For Rev 13:305-324

Pye-Smith C (2013) The quiet revolution: How Niger's farmers are re-greening the parklands of the Sahel. ICRAF Trees for Change no. 12. World Agroforestry Centre, Nairobi

Rands B, Rinaudo T (1990) Farmer-managed natural regeneration in Niger. NRMS Newsletter Summer 1990:5-6

Reij C (2010-2013) Africa Regreening Initiatives. Vrije University. http://africa-regreening.blogspot.com.au/. Accessed 9 June 2013

Reij C, Tappan G, Smale M (2009) Regreening the Sahel - Farmer led innovation in Burkina Faso and Niger. In: Spielman D, Pandya-Lorch R (eds) Millions Fed - Proven Successes in Agricultural Development. International Food Policy Research Institute, Washington DC, pp 53-58

Reij CP, Smaling E (2008) Analyzing successes in agriculture and land management in Sub-Saharan Africa: Is macrolevel gloom obscuring positive micro-level change? Land Use Policy 25:410-420

Rinaudo T (2007) The development of Farmer Managed Natural Regeneration. LEISA 23:32-34

Rinaudo T (2012) Farmer managed natural regeneration: Exceptional impact of a novel approach to reforestation in SubSaharan Africa. In: Motis T, Berkelaar D (eds) Agricultural Options for the Poor - a handbook for those who serve them. Educational Concerns for Hunger Organisation (Echo Inc), North Fort Myers

Samaké O, Dakouo JM, Kalinganire A, Bayala J and Koné B (2011) Régénération naturelle assistée - Gestion des arbres champêtres au Sahel. ICRAF Technical Manual No. 16. World Agroforestry Centre, Nairobi

Samaké O, Smaling EMA, Kropff MJ, Stomph TJ, Kodio A (2005) Effects of cultivation practices on spatial variation of soil fertility and millet yields in the Sahel of Mali. Agric Ecosyst Environ 109:335-345

Sanchez P, Swaminathan M (2005) Cutting hunger in half. Science 307:357-359

Scoones I (1998) Sustainable rural livelihoods: A framework for analysis. Institute of Development Studies, London 
Sendzimir J, Reij CP, Magnuszewski P (2011) Rebuilding resilience in the Sahel: Regreening in the Maradi and Zinder Regions of Niger. Ecol Soc 16:3

Simons AJ, Leakey RR (2004) Tree domestication in tropical agroforestry. Agrofor Syst 61:167-181

Taylor C, Lambin E, Stephenne N, Harding R, Essery R (2002) The influence of land use on climate change in the Sahel. J Clim 15:3615-3629

Taylor GF, Rands BC (1991) Trees and forest in the management of rural areas in the West African Sahel: Farmer managed natural regeneration. In: Proceedings of the 10th World Forestry Congress, Paris, France, 17-26 September. Vol 3. pp 49-55

Thorlakson T, Neufeldt H (2012) Reducing subsistence farmers' vulnerability to climate change: evaluating the potential contributions of agroforestry in western Kenya. Agric Food Secur 1:15

Tougiani A, Guero C, Rinaudo T (2009) Community mobilisation for improved livelihoods through tree crop management in Niger. GeoJournal 74:377-389

UNCCD, CFC (2009) The African Drylands Commodity Atlas. Secreatariat of the United Nations Convention to Combat Desertification and the Common Fund for Commodities, Bonn

UNDP (2011) Human Development Report 2011. United Nations Development Program, New York

Van Haaften E, Van der Vijver J (2003) Human resilience and environmental degradation: the eco-cultural link in the Sahel. Int J Sustain Dev World Ecol 10:85-99

Walker B, Gunderson L, Kinzig A, Folke C, Carpenter S, Schultz L (2006) A handful of heuristics and some propositions for understanding resilience in social-ecological systems. Ecol Soc 11:13

Weston P, Hong R (2013a) Talensi Farmer-Managed Natural Regeneration Project, Ghana: Social Return on Investment Report. World Vision Australia, http://fmnrhub.com.au/sroi-report-measuring-the-impact-offmnr/\#.VHRqs01xmM8

Weston P, Hong R (2013b) Talensi FMNR end-of-project evaluation report. World Vision Australia, unpublished

Woolcock M (1998) Social capital and economic development: Toward a theoretical synthesis and policy framework. Theory Soc 27:151-208

Woomer M, Tieszen L, Tappan G, Toure A, Sall M (2004) Land use changes and terrestrial carbon stocks in Senegal. J Arid Environ 59:625-642

Wopereis M, Tamelokpo A, Ezui D, Gnakpenou D, Fofana B, Breman H (2006) Mineral fertiliser management of maize on farmer fields differing in organic inputs in the West African savanna. Field Crop Res 96:355-362

World Bank (2013) Country data: Ghana. World Bank. http://data.worldbank.org/country/ghana.

WRI (2008) Turning back the desert: how farmers have transformed Niger's landscapes and livelihoods. In: Angell P (ed) World Resources 2008: Roots of resilience: growing the wealth of the poor. UNDP, UNEP, World Bank, and World Resources Institute, Washington DC, pp 142-157

Wright S, Nelson JD, Cooper JM, Murphy S (2009) An evaluation of the transport to employment (T2E) scheme in Highland Scotland using social return on investment (SROI). J Transp Geogr 17:457-467

WVG (2008) Talensi FMNR project design document. World Vision Ghana, Accra, Ghana

Yaro JA (2006) Is deagrarianisation real? A study of livelihood activities in rural northern Ghana. J Mod Afr Stud 44:125-156 